\title{
Description of Vagococcus coleopterorum sp. nov., isolated from the intestine of the diving beetle, Cybister lewisianus, and Vagococcus hydrophili sp. nov., isolated from the intestine of the dark diving beetle, Hydrophilus acuminatus, and emended description of the genus Vagococcus
}

\author{
Dong-Wook Hyun, Euon Jung Tak, Pil Soo Kim, and Jin-Woo Bae \\ Department of Biology and Department of Life and Nanopharmaceutical Sciences, Kyung Hee University, Seoul 02447, Republic of Korea
}

\begin{abstract}
In the article by Hyun et al. published in Journal of Microbiology 2021; 59, 132-141,
The figure on line 11 in the Abstract should be corrected to $98.8 \%$.

The sentence 'We propose the name Vagococcus coleopterorum sp. nov. for strain HDW17A' $\left(=\mathrm{KACC}^{\top} 21348^{\top}=\mathrm{KCTC}^{\top} 49324^{\top}\right.$ $\left.=\mathrm{JCM} 33674^{\top}\right)$ and the name Vagococcus hydrophili sp. nov. for strain HDW17B $\left(=\mathrm{KACC} 21349^{\top}=\mathrm{KCTC}^{\top} 49325^{\top}=\mathrm{JCM}^{\top}\right.$ $33675^{\top}$ ).' should be corrected to 'We propose the name Vagococcus coleopterorum sp. nov. for strain HDW17A ${ }^{\top}\left(=\mathrm{KACC}^{\mathrm{T}}\right.$ $21344^{\top}=$ KCTC $\left.43112^{\top}=\mathrm{JCM} 33682^{\dagger}\right)$ and the name Vagococcus hydrophili sp. nov. for strain HDW17B ${ }^{\top}\left(=\mathrm{KACC}^{21345^{\top}}\right.$ $\left.=\operatorname{KCTC~} 43113^{\top}=\mathrm{JCM} 33683^{\mathrm{T}}\right)$.' in the Abstract.
\end{abstract}

The Abstract should have read:

A polyphasic taxonomic approach was used to characterize

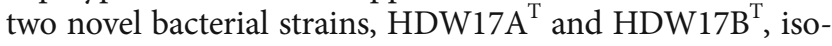
lated from the intestine of the diving beetle Cybister lewisianus, and the dark diving beetle Hydrophilus acuminatus, respectively. Both strains were Gram-positive and facultative anaerobic cocci forming cream-colored colonies. The isolates grew optimally at $25^{\circ} \mathrm{C}, \mathrm{pH} 7$, in the presence of $0.3 \%$ (wt/vol) $\mathrm{NaCl}$. Phylogenetic analysis based on $16 \mathrm{~S}$ rRNA gene sequences and genome sequences showed that the isolates were members of the genus Vagococcus, and strain $\mathrm{HDW}_{17 \mathrm{~A}^{\mathrm{T}}}$ was closely related to Vagococcus fessus CCUG $41755^{\mathrm{T}}(98.8 \%$ of $16 \mathrm{~S}$ rRNA gene sequence similarity and $74.3 \%$ of average nucleotide identity [ANI]), whereas strain $\mathrm{HDW}_{17 \mathrm{~B}^{\mathrm{T}} \text { was }}$ closely related to Vagococcus fluvialis NCFB $2497^{\mathrm{T}}$ (98.9\% of $16 \mathrm{~S}$ rRNA gene sequence similarity and $76.6 \%$ of ANI). Both strains contained C16:0, and C18:1 $\omega 9 \mathrm{c}$ as the major cellular fatty acids, but C16:1 $\omega 9 \mathrm{c}$ was also observed only in strain $\mathrm{HDW} 17 \mathrm{~B}^{\mathrm{T}}$ as the major cellular fatty acid. The respi- ratory quinone of the isolates was MK-7. The major polar lipid components were phosphatidylglycerol, phosphatidylethanolamine, and diphosphatidylglycerol. The genomic DNA G + C content of strains HDW17A ${ }^{\mathrm{T}}$ and $\mathrm{HDW} 17 \mathrm{~B}^{\mathrm{T}}$ were 36.6 and $34.4 \%$, respectively. Both strains had cell wall peptidoglycan composed of the amino acids L-alanine, glycine, D-glutamic acid, L-tryptophan, L-lysine, and L-aspartic acid, and the sugars ribose, glucose, and galactose. Based on phylogenetic, phenotypic, chemotaxonomic, and genotypic an-

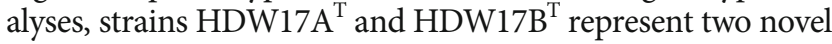
species in the genus Vagococcus. We propose the name Vagococcus coleopterorum sp. nov. for strain HDW $17 \mathrm{~A}^{\mathrm{T}}$ (= KACC $21344^{\mathrm{T}}=$ KCTC $43112^{\mathrm{T}}=\mathrm{JCM} 33682^{\mathrm{T}}$ ) and the name Vagococcus hydrophili sp. nov. for strain $\mathrm{HDW}_{17 \mathrm{~B}^{\mathrm{T}}}$ (= KACC $21345^{\mathrm{T}}=\operatorname{KCTC} 43113^{\mathrm{T}}=\operatorname{JCM} 33683^{\mathrm{T}}$ ).

Authors apologize for any inconvenience that this may have caused. 